\title{
EFFECT OF LOW LEVEL LASER THERAPY ON PAIN LEVEL AFTER THIRD MOLAR SURGERY: A META-ANALYSIS
}

\author{
Nita Layli Hanifah'), Eti Poncorini Pamungkasari²), \\ Rita Benya Adriani2)
}

\author{
1)Masters Program in Public Health, Universitas Sebelas Maret \\ ${ }^{2)}$ Department of Public Health, Faculty of Medicine, Universitas Sebelas Maret
}

\begin{abstract}
Background: Low-level laser therapy is a form of light therapy that triggers biochemical changes within cells. Photons are absorbed by cellular photoreceptors, triggering chemical alterations and potential biochemical benefits to the human body. Lowlevel laser therapy has been used in pain management for years and is also known as cold laser therapy, which uses low-frequency continuous laser of typically 600 to $1,000 \mathrm{~nm}$ wavelength for pain reduction and healing stimulation. This study aimed to examine the effect of low level laser therapy on pain level after third molar surgery.

Subjects and Method: A systematic review and meta-analysis was conducted by collecting articles published from 2005 to 2021. Articles search source were PubMed, Science Direct, Springer Link, Google Scholar, and Chorance Library databases. The inclusion criteria were English full text and randomized controlled trial. Keywords used "Low level laser therapy" AND "Pain level" AND "Third molar surgery" AND "Randomized Controlled Trial". The articles were filtered using PICO model, including: (1) Population $=$ patient of third molar surgery aged $18-45$ years, $(2)$ intervention $=$ low level laser therapy, (3) comparison= non low level laser therapy, and (4) outcome $=$ pain. Quantitative data analysis was processed by calculating standardized mean difference using Review Manager (RevMan 5.3).

Results: 10 studies were involved for meta-analysis. The study showed that low level laser therapy was effective to lower pain in patients whose undergo third molar surgery (Standarized Mean Difference $=-0.86 ; 95 \% \mathrm{CI}=-1.19$ to $-0.53 ; \mathrm{p}=0.004$ ). This study indicated that there was no publication bias between studies.

Conclusion: Low level laser therapy is effective to lower pain in patients whose undergo third molar surgery.
\end{abstract}

Keywords: low level laser therapy, pain, third molar surgery

\section{Korespondensi:}

Nita Layli Hanifah. Masters Program in Public Health, Universitas Sebelas Maret. Jl. Ir. Sutami 36A, Surakarta 57126, Central Java. Email: Nitalaylii63@gmail.com. 